\title{
Effects of turmeric rhizome powder on growth, carcass and meat quality of Japanese quails fed sorghum- soybean-based diets
}

\author{
O.O.O. Kennedy* ${ }^{1}$, E.N. Mbaba ${ }^{2}$, I.E. Iso $^{3}$, A. Halilu ${ }^{1}$, A.N. Robert ${ }^{1}$,
} A. N. \& B. Micheal

${ }^{1}$ Department of Animal Science, Faculty of Agriculture, Forestry and Wildlife Resources Management, University of Calabar; ${ }^{2}$ Department of Animal Science, Faculty of Agriculture, University of Uyo; ${ }^{3}$ Department of Animal Science, Cross River University of Technology, Obubra Campus, Nigeria

*corresponding author: oluwatosin.kennedyoko@gmail.com; oluwatosin.kennedyoko@unical.edu.ng

Journal of Livestock Science (ISSN online 2277-6214) 11: 1-7

Received on 15/10/2019; Accepted on 2/1/2020

doi. 10.33259/JLivestSci.2020.1-7

\begin{abstract}
This study was conducted with 600, seven day-old mixed Japanese quail chicks to investigate the effects of varying levels of turmeric rhizome powder (TRP) on growth parameters, carcass traits and organoleptic properties of the breast muscles. The chicks were randomly assigned to five dietary groups containing 0.00 , $0.25,0.50,0.75$ and $1.00 \%$ TRP of sorghum-soybean based diet in a completely randomized design. Each treatment had six replicates of 20 birds each and was studied from 7 - 42 days of age. Growth performance (body weight, weight gain, feed intake, feed conversion ratio and mortality), carcass characteristics (dressed weight, dressing percent, breast and gastrointestinal weights) and organoleptic properties (colour, flavor, juiciness, texture, number of chews, remains after and overall acceptability) were measured. One-way ANOVA was used for data analysis and significant means separated using the least significant difference methods. Inclusion of TRP in the diet increased $(\mathrm{P}<0.05)$ all growth parameters, especially at $0.50 \%$ inclusion without any adverse effect $(\mathrm{P}>0.05)$ on carcass traits. Mean scores for organoleptic evaluation of meat showed that TRP had no influence $(\mathrm{P}>0.05)$ quail breast muscle. This study concludes that TRP significantly improved growth without altering the carcass and organoleptic properties of breast muscle of Japanese quails. Dietary supplementation with $0.50 \%$ TRP is thus recommended for quails fed sorghum-soybean based diet.
\end{abstract}

Keywords: Spices; growth enhancer; responses; dressing yield; quails 


\section{Introduction}

The Japanese quail (Coturnix coturnix japonica) is gaining attention as the ideal poultry species for meeting the animal protein needs in most developing countries (Oko and Agiang, 2011). It is suited for commercial rearing, meat and egg production under intensive management. Moreso, its relative faster rate of maturity, egg production and cheaper production cost make commercial quail farming a choice venture (Abang et al., 2017).

Feed cost has remained the major factor hindering sustainable animal production (Oko and Agiang, 2011). Specifically, the overdependence on maize as the main energy source for animal feed coupled with its competition by man for various domestic and industrial uses has led to the incessant high cost of feeds. Consequently, the high cost of production and collapse of several small-scale poultry farms (Abang et al., 2017). Researchers are thus challenged to explore alternative energy sources such as sorghum grains that have comparable feeding values as maize for incorporation into poultry diets (Ghaedi et al., 2018).

Sorghum is currently being incorporated into poultry diets (Liu et al., 2015). However, the presence of tannin and its production of white meat against the characteristics yellow meat preferred by consumers limits its utilization. Consumers' preference for safe, quality and affordable meat products has led to the exploitation of feed additives with health benefits, of which Turmeric is being considered (Amalraj et al., 2017). Several processing methods such as drying and grinding could reduce the tannin contents of sorghum, more so biofortification with feed additives (that possess colouring principles such as turmeric) have been shown to improve poultry meat quality (Agiang et al., 2011).

Turmeric (Curcuma longa) is an indigenous herb of southern and south eastern Asia of the ginger family - Zingibireceae (Gumus et al., 2018). According to Emadi et al. (2007), the rhizome is widely used as spice, colouring agent and medicinal remedies. Turmeric rhizome powder (TRP) contains several bioactive principles; tetrahydrocurcuminoids, curcumin, demethoxycurcumin and bisdemethoxycurcumin (Jurenka, 2009) that exhibit antioxidative, anticarcinogenic, (Amalraj et al., 2017), digestive and antimicrobial properties which are required for the production of healthy poultry and safe products (Kermanshahi \& Riasi, 2010). TRP has been reported to contain $60-70 \%$ carbohydrate, $6-8 \%$ protein, $5-10 \%$ fat, $2-7 \%$ fibre, $6-13 \%$ water, , $3-$ $7 \%$ dietary minerals, $3-7 \%$ essential oils, and $1-6 \%$ curcuminoids, these properties make turmeric a potential alternative growth promoter in livestock feeds (Kilany and Mahmoud, 2014).

Recent studies have shown that turmeric powder is used as dietary supplement to improve poultry performances and stimulate their immune system (Qasem et al., 2015), however the efficacy of TRP in poultry remains varied. Some reports showed positive effect on birds at 0.5 - 1.0\% TRP (Al-Sultan, 2003; Qasem et al., 2015), few no effects (Emadi and Kermanshahi, 2006;) others revealed negative effects of TRP (Durrani et al., 2006). Most researches have also been concentrated on broilers fed corn-soybean diets (Qasem et al., 2015; Gumus et al., 2018). Where used in quails, it was supplemented with exogenous enzyme (Kilany and Mahmoud, 2014) or in corn-soybean diet (Saraswati and Tana, 2016). This study was therefore designed to investigate the efficacy of TRP as a dietary supplement in a sorghum-soybean based-diet on the growth, carcass and organoleptic properties of breast muscles of Japanese quails.

\section{Materials and Methods Location of experiment}

The field trial was carried out at the Poultry unit of the Teaching and Research Farm of the University of Calabar, Calabar, Nigeria from the month of August to October, 2018. Calabar is located in the South - south region of the country at latitude $4^{\prime} 75 \mathrm{~N}$ and longitude $8^{\prime} 19^{\circ} \mathrm{E}$ with an annual rainfall of $1260-1280 \mathrm{~mm}$, average temperature of $25-30^{\circ} \mathrm{C}$, relative humidity of $60-80 \%$ with an elevation of $99 \mathrm{~m}$ above sea level (NMA, 2018).

\section{Preparation of materials}

Fresh turmeric rhizomes were purchased from local markets in Calabar, Nigeria. They were washed, sliced into $2 \mathrm{~mm}$ pieces and sundried for 96 hours. The dried turmeric rhizomes was ground in a mill (in a herbal shop in Calabar Metropolis city) and sieve using a $1 \mathrm{~mm}$ mesh sieve to obtain turmeric rhizome powder (TRP). TRP was stored in dry, air tight containers until needed for further use to prevent contamination and mould infestation. Proximate chemical composition of TRP was determined using the AOAC (2010) methods.

\section{Experimental diets}

TRP was included at $0.00,0.25,0.50,0.75$ and $100 \%$ into the sorghum-soybean starter ( 7 - 21 days of age) and grower (22- 42 days of age) diets to meet quail nutrient requirements as shown in Table 1.

\section{Birds and management}

Six hundred (600), seven day-old mixed Japanese quails chicks (mean mass of $34.90 \pm 0.02 \mathrm{~g}$ ) purchased from the National Veterinary Research Institute, Vom in Plateau State, Nigeria were studied from 7 42 days. The quail chicks were allocated to the five experimental groups with six replicates of 20 quail chicks each. The chicks were managed under continuous lighting and ambient temperature in the pen was initially 
maintained at $30^{\circ} \mathrm{C}$ and gradually reduced to $25^{\circ} \mathrm{C}$ at day 36 . Feed and water were provided ad libitum throughout the experiment.

Table 1. Gross composition of basal diets (\%)

\begin{tabular}{|l|c|c|}
\hline Ingredient & Starter & Grower \\
\hline Sorghum & 41.00 & 40.00 \\
\hline Soybean & 42.00 & 38.00 \\
\hline Wheat offal & 6.00 & 7.00 \\
\hline Crayfish dust & 2.00 & 2.00 \\
\hline Palm kernel cake & 4.00 & 8.00 \\
\hline Palm oil & 1.00 & 1.00 \\
\hline Di-calcium phosphate & 3.00 & 3.00 \\
\hline Methionine & 0.25 & 0.25 \\
\hline Lysine & 0.25 & 0.25 \\
\hline Salt & 0.25 & 0.25 \\
\hline *Vitamin premix & 0.25 & 0.25 \\
\hline Total & $\mathbf{1 0 0 . 0 0}$ & $\mathbf{1 0 0 . 0 0}$ \\
\hline & & 24.88 \\
\hline Crude protein & 25.87 & 4.22 \\
\hline Crude fibre & 3.89 & 1.25 \\
\hline Calcium & 1.25 & 3016.90 \\
\hline Metabolizable energy $(\mathrm{kcal} / \mathrm{kg})$ & 3075.20 & $\mathrm{~A}$ (rients \\
\hline
\end{tabular}

*Vitamin BCP (premix; 0.25\% vitamins and Trace elements), each 2.5kg supplied the following: Vitamin A 10,000,000 I.U, Vitamin D 2,000,000 I.U, Vitamin E 20,000I.U, Vitamin K 2,250mgr, Thiamine 1,750mgr, Riboflavin B 5,000mgr, Pyridoxine $\mathrm{B}_{6}$ 2,750 mgr, Niacin 27,500 mgr, Vitamin $\mathrm{B}_{12} 15 \mathrm{mgr}$, Pantothenic acid 7,500 mgr, Biotin 50 mgr, Cholin chloride 400gr, Antioxidant 125 gr, Manganese 80 gr, Zinc 50 gr, Iron 20 gr, Copper 5 gr, Iodine 1.20 gr, Selenium 200 gr, Cobalt 200 gr

\section{Data collection}

Growth performance of each treatment group was assessed in terms of their body mass, weight gain, feed intake and feed conversion ratio on a weekly basis. Feed and water were provided daily, the quails were fed twice at $8.00 \mathrm{hr}$ and $16.00 \mathrm{hr}$. Percentage mortality was recorded daily as it occurred between treatment groups. Therefore, weekly average growth parameters were estimated. Cost benefit ratio was calculated at the 35 days of experiment.

At the end of the experiment (day 42 of age), four birds were randomly picked per replicate with a total of 120 quails $(4 \times 6 \times 5)$ used for carcass analysis. Prior to slaughter, the quails were starved for 12 hours and individually weighed to obtain their live weights. Each bird was slaughtered by cervical dislocation and allowed to bleed. The carcasses were dissected, their internal organs immediately excised, feathers were plunged using warm water $\left(60^{\circ} \mathrm{C}\right)$ and carcasses dressed. Dressed weight was measured and dressed, breast, full gastrointestinal and visceral fat pad were weighed and expressed as percentage of live weight.

Three pieces of meat were collected from the left breast muscle of each carcass for proximate (dry matter, crude protein, ether extract, and crude ash contents) and organoleptic (sensory test for colour, flavor, chewiness, juiciness and overall acceptability) analyses. The two meat samples were collected in plastic plates, weighed, stored in airtight bags then refrigerated at $4^{0} \mathrm{C}$ for $24 \mathrm{~h}$.

Samples for proximate analysis were thawed and homogenized using a blender and analyzed for dry matter (by oven drying at $105^{\circ} \mathrm{C}$ at $18 \mathrm{~h}$ ). Soxhlet extraction using anhydrous diethylether was used for ether extract determination while, the Kjedahl method was used in analysing the total nitrogen content and crude protein was expressed as Nitrogen x 6.25. Crude ash content was determined using a metal muffle furnace at $550^{\circ} \mathrm{C}$ for $16 \mathrm{~h}$. All methods were carried out according to the AOAC (2010) procedures and all values were expressed on dry matter basis.

Sample for sensory test was pressure cooked at $15 \mathrm{lb}$ pressure for $5 \mathrm{mins}$, thereafter subjected to taste panel evaluation at the Food Science and Technology Laboratory, University of Calabar. Codified samples were served immediately to 25 semi-trained panelists (to prevent biases, persons not familiar with the meat scoring procedures between ages of 18-30 were selected and trained on how to score for each test) given the 7-point Hedonic score card as shown in Table 2, to examine the meat colour, flavour, tenderness, juiciness and overall acceptability as highlighted by Choudhury et al. (2019). 


\section{Statistical Analysis}

One-way analysis of variance according to the method of Steel and Torrie (1980) was used to analyse the data collected. Significant means were separated by the Duncan multiple range test using the GENSTAT Release 15 (GENSTAT, 2012) statistical package.

The feeding experiment was conducted according to the guidelines approved by the Animal Ethics Committee of The University of Calabar (Nigeria) and the NIH standards described in the NRC (2011) Guide for the Care and Use of Laboratory Animals.

Table 2: Hedonic scale for meat sensory score

\begin{tabular}{|l|c|}
\hline Remark & Score \\
\hline Excellent & 7 \\
\hline Very good & 6 \\
\hline Good & 5 \\
\hline Fair & 4 \\
\hline Poor & 3 \\
\hline Very poor & 2 \\
\hline Extremely poor & 1 \\
\hline
\end{tabular}

Table 3: Growth performance of quails fed turmeric-sorghum based diet

\begin{tabular}{|c|c|c|c|c|c|c|}
\hline Parameters & \begin{tabular}{|l} 
Sorghum \\
0.00\% TRP
\end{tabular} & $\begin{array}{l}\text { Sorghum } \\
+0.25 \% \text { TRP }\end{array}$ & $\begin{array}{l}\text { Sorghum } \\
+\mathbf{0 . 5 0 \%} \text { TRP }\end{array}$ & $\begin{array}{l}\text { Sorghum } \\
+0.75 \% \text { TRP }\end{array}$ & $\begin{array}{l}\text { Sorghum } \\
+1.00 \% \text { TRP }\end{array}$ & SEM \\
\hline Initial weight, $\mathrm{g}$ & 34.90 & 34.90 & 34.90 & 34.90 & 34.90 & 0.10 \\
\hline Final weight, $g$ & $125.55^{\mathrm{ab}}$ & $127.45^{\mathrm{b}}$ & $134.30^{\mathrm{a}}$ & $125.55^{b}$ & $124.15^{\mathrm{b}}$ & 0.04 \\
\hline Daily weight gain, g/day & $2.59^{\mathrm{b}}$ & $2.67^{\mathrm{b}}$ & $2.84^{\mathrm{a}}$ & $2.59^{\mathrm{b}}$ & $2.55^{\mathrm{b}}$ & 0.04 \\
\hline Daily feed intake, g/day & $16.66^{\mathrm{a}}$ & $16.50^{\mathrm{ab}}$ & $16.38^{b}$ & $16.40^{b}$ & $16.23^{b}$ & 0.03 \\
\hline Feed Conversion Ratio & $6.43^{\mathrm{a}}$ & $6.18^{\mathrm{a}}$ & $5.77^{\mathrm{b}}$ & $6.33^{\mathrm{a}}$ & $6.37^{\mathrm{a}}$ & 0.04 \\
\hline Feed cost/bird ( & 131.56 & 132.97 & 133.21 & 133.75 & 133.83 & 0.08 \\
\hline Survivability, \% & 91.30 & 92.42 & 93.55 & 93.55 & 94.42 & 0.45 \\
\hline
\end{tabular}

SEM = Standard error of means; $a, b=$ means with different superscripts on the same row differ $(\mathrm{P}<0.05)$ significantly

Table 4: Carcass characteristics of quails fed turmeric-sorghum diets

\begin{tabular}{|l|l|l|l|l|l|l|}
\hline Parameters & $\begin{array}{l}\text { Sorghum } \\
\mathbf{0 . 0 0 \%} \text { TRP }\end{array}$ & $\begin{array}{l}\text { Sorghum } \\
+\mathbf{0 . 2 5 \%} \text { TRP }\end{array}$ & $\begin{array}{l}\text { Sorghum } \\
+\mathbf{0 . 5 0 \%} \text { TRP }\end{array}$ & $\begin{array}{l}\text { Sorghum } \\
+\mathbf{0 . 7 5 \%} \text { TRP }\end{array}$ & $\begin{array}{l}\text { Sorghum } \\
+\mathbf{1 . 0 0 \%} \text { TRP }\end{array}$ & SEM \\
\hline Live weight, g & 133.50 & 134.67 & 135.00 & 122.83 & 125.83 & 3.93 \\
\hline Dressed weight, g & 98.33 & 98.35 & 99.20 & 91.83 & 96.17 & 2.28 \\
\hline \% Dressing & $73.66^{\mathrm{b}}$ & $73.03^{\mathrm{b}}$ & $73.48^{\mathrm{b}}$ & $74.76^{\mathrm{ab}}$ & $76.43^{\mathrm{a}}$ & 0.05 \\
\hline Breast, \% LW & 25.60 & 25.68 & 25.75 & 25.78 & 25.83 & 0.65 \\
\hline GIT weight, \%LW & 13.48 & 13.35 & 13.33 & 13.27 & 13.25 & 0.26 \\
\hline $\begin{array}{l}\text { Abdominal fat pad, \% } \\
\text { LW }\end{array}$ & $3.18^{\mathrm{a}}$ & $2.63^{\mathrm{b}}$ & $1.86^{\mathrm{c}}$ & $1.79^{\text {cd }}$ & $1.59^{\mathrm{d}}$ & 0.03 \\
\hline
\end{tabular}

$\mathrm{SEM}=$ Standard error of means, ${ }^{\mathrm{a}, \mathrm{b}, \mathrm{c} \text { and } \mathrm{d}}$ Mean indicate significant $(\mathrm{P}<0.05)$ differences between treatments across row.

Table 5. Sensory evaluation of breast meat from quails fed turmeric-sorghum diets

\begin{tabular}{|l|l|l|l|l|l|l|}
\hline Parameters & $\begin{array}{l}\text { Sorghum } \\
\text { diet, } \mathbf{0 . 0 0 \%} \\
\text { TRP }\end{array}$ & $\begin{array}{l}\text { Sorghum } \\
+\mathbf{0 . 2 5 \%} \\
\text { TRP }\end{array}$ & $\begin{array}{l}\text { Sorghum } \\
+\mathbf{0 . 5 0 \%} \text { TRP }\end{array}$ & $\begin{array}{l}\text { Sorghum } \\
+\mathbf{0 . 7 5 \%} \text { TRP }\end{array}$ & $\begin{array}{l}\text { Sorghum } \\
+\mathbf{1 . 0 0 \%} \text { TRP }\end{array}$ & SEM \\
\hline Colour & 5.33 & 5.67 & 5.80 & 5.90 & 5.92 & 0.25 \\
\hline Flavour & 5.00 & 5.00 & 5.33 & 5.33 & 5.70 & 0.28 \\
\hline Tenderness & 5.27 & 5.67 & 5.67 & 5.33 & 5.75 & 0.37 \\
\hline Juiciness & 5.45 & 5.65 & 5.65 & 5.65 & 5.56 & 0.34 \\
\hline Number of chew & 5.33 & 5.67 & 5.00 & 5.33 & 5.67 & 0.45 \\
\hline Remains after chewing & 4.67 & 5.33 & 5.33 & 5.33 & 5.67 & 0.64 \\
\hline Overall acceptability & 5.80 & 5.99 & 6.35 & 5.85 & 5.85 & 0.15 \\
\hline
\end{tabular}

$\mathrm{SEM}=$ Standard error of means, N/B: No significant $(\mathrm{P}>0.05)$ differences between treatments across row 


\section{Results}

Table 3 shows the values of final body weight, body weight gain, average daily gain, feed intake, feed conversion ratio and mortality of quails fed the experimental diets. The inclusion of TRP to sorghum diet significantly $(\mathrm{P}<0.05)$ influenced all growth parameters measured. Final body weight ranged from $124.15-$ $134.30 \mathrm{~g}(\mathrm{P}=0.042)$ and quails on $0.5 \% \mathrm{TRP}$ had heavier weight compared to other dietary treatments. At $1.00 \%$ TRP supplementation, body weight was slightly depressed.

Daily weight gain $(2.55-2.84 \mathrm{~g}, \mathrm{P}=0.038)$ followed similar trend as quails on $0.5 \%$ TRP had higher $(\mathrm{P}<0.05)$ gains compared to the control and other TRP supplemented diets. The addition of $0.5 \%$ TRP into sorghum diet improved daily gain by $9.84 \%$, while at $1.00 \%$ TRP daily gain was depressed by $1.54 \%$.

Dietary supplementation with TRP lowered $(\mathrm{P}>0.05)$ daily feed intake in Japanese quails. Quails on sorghum diet without TRP recorded the highest intake $(16.66 \mathrm{~g} / \mathrm{day} / \mathrm{bird})$ with the least in quails on $1.00 \% \mathrm{TRP}$ (16.23.g/day). Feed conversion ratio (FCR) of Japanese quails was influenced $(\mathrm{P}<0.05)$ by dietary treatments. The best FCR $(5.77, \mathrm{P}=0.036)$ was achieved at $0.5 \%$ TRP supplementation compared to the control group (6.43) and other dietary treatments. Results revealed up to $10.26 \%$ improvement in sorghum utilization by quails following TRP supplementation. Survivability $(91.30-94.42 \%)$ was high across the treatments but quails on $1.00 \%$ TRP had reduced mortality $(\mathrm{P}>0.05)$ compared to values recorded in the control (\%) group.

\section{Carcass characteristics}

The slaughter weight, dressed weight, relative breast and gastrointestinal weights were not affected $(\mathrm{P}>0.05)$ by dietary treatments (Table 4). TRP however influenced $(\mathrm{P}<0.05)$ dressing percentage, and relative abdominal fat pad between treatments.

The dressing percentage of edible carcass yield and abdominal fat pad ranged from 73.03 to $76.43 \%$ and 1.59 $3.18 \%$, respectively. It was that the abdominal fat pad decreased $(\mathrm{P}<0.05)$ with increased dressing percentage as TRP increases in the diet, indicative of improved meat quality compared to the control diet.

\section{Meat Score}

Table 5 indicated no differences $(\mathrm{P}>0.05)$ in the mean scores for sensory evaluation of breast muscle of quails on varying levels of TRP in sorghum-soybean diet. Mean Overall acceptability score ranged from 5.80 - 6.35, implying that the meat is of good to very good quality. Meat colour and flavor increased $(\mathrm{P}>0.05)$ at higher TRP supplementations.

\section{Discussion}

Final body weight obtained fell within previous values $(97-134.33 \mathrm{~g}$ and 126.33 - 138.33g) reported by Abang et al. (2017) for quails fed Prosopisafricana seed coat meal. Bonus et al. (2010) and Kilany and Mahmoud (2014) had reported higher bodyweight of $152.30-160.00 \mathrm{~g}$ and 189.76- 200.94g in quails fed turmeric-enzyme diets. The strain, feed and environmental conditions could affect variations observed.

Daily feed intake values in the present study were within the ranges $(11.60-19.14 \mathrm{~g} / \mathrm{day}$ and $13.15-$ $15.25 \mathrm{~g} /$ day) reported by Vali (2009) and Bonos et al. (2010) for quails. . Findings of Vali (2009) had shown a FCR value of 7.09 in Japanese quails. Our result is similar with previous reports (Durrani et al., 2006; Mondal et $a l ., 2015$ ) that indicated improved FCR when TRP was supplemented at $0.5 \%$ into broiler diet.

Increasing TRP to $1.00 \%$ improved the survivability of Japanese quails. This might be due to the presence of antioxidant and antimicrobial properties of turmeric and their ability to suppress pathogenic bacteria thus promoting the immune status of the birds. Findings of Kilany and Mahmoud (2014) also showed nonsignificant improvement of turmeric supplemented diets on the survivability of bird. Daneshyar et al.(2012) however reported significant reduction in mortality rate in broilers fed turmeric powder, whereas, Mondal et al. (2015) observed no effects on survivability rate following turmeric supplementation. Variation in results could be due to the strains, turmeric species used or management practiced.

The better performance exhibited in quails fed TRP supplemented-sorghum diet indicated that, turmeric due to its rich bioactive components as curcumoinoids and curcumin could encourage the bioavailability and utilization of nutrients by the birds. The tannin-effects of sorghum could have been suppressed with turmeric supplementation. These effects resulted to the enhanced metabolism and improved performance in quails which is in line with earlier observations (Al-Sultan and Gameel, 2004) that turmeric supplementations improved growth performances in broilers. Contrary to this present study, Kilany and Mahmoud (2014) observed no significant effect of TRP on the growth performance and feed utilization in Japanese quails. The differences observed could be due to the type of grain, nature of turmeric species, processing methods, environmental conditions and the species of quails used in the experiment.

On carcass characteristics, inclusion of $0.5 \%$ turmeric powder caused a non dose-dependent increase in dressed weight by $0.89 \%$ in comparison with the control and other turmeric-supplemented quails. The present findings on the dressing percentage of Japanese quails fed TRP supplementation indicated slight improvement 
in quail meat following supplementation. Previous reports have shown $52-57 \%$ dressed carcass in birds fed TRP diets (Al-Sultan, 2003; Mondal et al., 2015; Yesuf et al., 2017). Improvement in carcass yield is attributed to the antioxidant properties of turmeric due to the presence of curcumin, ar-tumerones and curlones which promote protein synthesis (Hussein, 2013). Yesuf et al. (2017) also noted that TRP could accelerates the quantity of lean meat ratio in poultry thus reducing the risk of hyperlipidemia in consumers. Results were consistent with the report of Choudhury et al. (2019) that TRP had no effect on the dressing percentage, organ and GIT weight of poultry.

The present result on meat sensory score is similar with the findings of Al-Sultan (2003) and Choudhury et al. (2019) who reported non-significant influence of turmeric powder on the organoleptic properties of broiler meat. Nevertheless, poultry meat with high abdominal fat deposit is considered a low quality product with reduced consumers' acceptability. Result from this finding indicated that $1.00 \%$ TRP supplementation to sorghum-soybean diet significantly $(\mathrm{P}<0.05)$ reduced visceral fat pad in quails compared to those on the control diet that received no TRP. This observation was consistent with previous reports (Hussein, 2013; Yesuf et al., 2017) which indicated that the inclusion of turmeric into poultry diets markedly reduced abdominal fat ratio. The significant reduction in abdominal fat could be due to the curcumin content present in turmeric, which suppresses preadipocyte differentiation through the down regulation of lipogenesis in the liver (Ferguson et al., 2016).

Generally, Improved growth, carcass and organoleptic meat score were observed in quails fed sorghum diet supplemented with $0.5 \%$ TRP. This agrees with the findings of Mondal et al. (2015) who reported significant impactof $0.5 \%$ TRP inclusionon broiler body weight gain, FCR, abdominal fat content, dressing percentage, meat quality and survivability. This affirms that dietary turmeric supplementation at $0.5 \%$ has high commercial applications as a growth enhancer in poultry.

\section{Conclusion}

This study concludes that $0.5 \%$ Tumeric Rhizome Powder should be included into sorghum-soybean diet for improved quail performances.

\section{Conflict of interest}

All authors have approved the submission of this manuscript and do declare that there is no conflict of interest. The manuscript has not been published previously and is not under consideration for publication elsewhere.

\section{References}

1) Abang FB, Oko OK, Yelwa JT, 2017. Carcass and organ characteristics of growing Japanese quails (Coturnix coturnix japonica) fed sun-dried mango (Mangifera spp) kernel meal as a replacement for maize. Annual Research and Review in Biology 20(6): 1-7.

2) Agiang EA, Oko OOK, Essien GE, 2011. Quails response to aqueous extract of bush marigold (Aspilia africana) leaf. American Journal of Animal and Veterinary Sciences 6(4): 130 - 134.

3) AL-Sultan SI, 2003. The effects of Curcuma longa (turmeric) on overall performance of broiler chickens. $\begin{array}{lllll}\text { International Journal of } & \text { 3nimal } & \text { Science } & \text { 251-353 }\end{array}$ https://pdfs.semanticscholar.org/e498/0f50d345bd331719e2c82b8587475a1402c1.pdf

4) Al-Sultan SI, Gameel AA, 2004. Histopathological changes in the livers of broiler chickens supplemented with turmeric (Curcuma longa). International Journal of Poultry Science 3(5): 333-336.

5) Amalraj A, Pius A, Gopi S, Gopi S, 2017. Biological activities of curcuminoids, others biomolecules from turmeric and their derivatives- a review. Journal of Traditional and Complementary Medicine 7: 205233.

6) AOAC, 2010. Official Methods of Analysis. Association of Official Analytical Chemists. $18^{\text {th }}$ Edition. Washington DC.

7) Bonos F, Christaki E, Florou-Paneri P, 2010. Performance and carcass characteristics of Japanese quail as affected by sex or manna oligosaccharides and calcium propionate. South African Journal of Animal Science 40:173-184.

8) Choudhury D, Mahanta JD, Sapcota D, Saikia BN, 2019. Effect of dietary supplementation of turmeric (Curcuma longa) powder on the carcass quality of commercial broiler chicken. International Journal of Food Science and Nutrition 4(1): 27-31.

9) Daneshyar M, Kermanshashi H, Golian A, 2012. The effects of turmeric supplementation on antioxidant status, blood gas indices and mortality in broilers with $\mathrm{T}_{3}$ induced ascites. British Poultry Science 53(3): 379-385.

10) Durrani FR, Ismail M, Sultan A, Suhail SM, Chand N, Durrani Z, 2006. Effect of different levels of feed added turmeric (Curcuma longa) on the performance of broiler chicks. Journal of Agricultural Biology and Environmental Statistics 1: 9-11. 
11) Emadi M, Kermanshahi H, 2006. Effect of turmeric rhizome powder on performance and carcass characteristics of broiler chickens. International Journal of Poultry Science 5: 1069-1072..

12) Emadi M, Kermanshahi H, Maroufyan E, 2007. Effect of varying levels of turmeric rhizome powder on some blood parameters of broiler chickens fed corn soybean meal based diets. International Journal of Poultry Science 6(5): 345-348.

13) Ferguson BS, Nam H, Morrison RF, 2016. Curcumin inhibits 3T3-L1 preadipocyte proliferation by mechanisms involving post-transcriptional p27 regulation. Biochemistry and Biophysics Reports 5: 1621.

14) GENSTAT, 2012. GENSTAT 15th Edition, VSN International Ltd (VSNi),

15) Ghaedi 1, Houshmand M, Parsaei S, 2018. Performance and tibia characteristics of broilers fed diets containing raw and treated oak acorn (Quercus brantiil L.). The Journal of Animal and Plant Sciences 28(1): $38-45$.

16) Gumus H, Oguz MN, Bugdayci KE, Oguz FK, 2018. Effects of sumac and turmeric as feed additives on performance, egg quality traits and blood parameters of laying hens. Revisita Brasileira de Zootecnia 47:e20170114.2018.

17) Hussein SN, 2013. Effect of turmeric (Curcuma longa) on growth performance, carcass traits, meat quality and serum biochemical parameters in broilers. Journal of Advanced Biomedical and Pathobiology Research 3: 25-32.

18) Jurenka S, 2009. Anti- inflammatory properties of curcmin, a major constituent of Curcuma longa: a review of preclinical and clinical research. Alternative Medicine Review: 141-153. https://www.ncbi.nlm.nih.gov/pubmed/19594223.

19) Kermanshahi H, Riasi A, 2010. Effect of turmeric rhizome powder (Curcuma longa) and soluble NSP degrading enzyme on some blood parameters of laying hens. International Journal of Poultry Science 5(5): 494-498.

20) Kilany OE, Mahmoud MMA, 2014. Turmeric and exogenous supplementation improve growth performance and immune status of Japanese quail. World Veterinary Journal 4(3): 20-29.

21) Liu SY, Selle PH, 2015. A consideration of starch and protein digestive dynamics in chicken-meat production. World's Poultry Science Journal 71:297-310.

22) Mondal MA, Yeasmin T, Karim K, Siddiqui MN, Sayed MA, 2015. Effect of dietary supplementation turmeric (Curcuma longa) powder on performance, carcass traits of broiler chicks. SAARC Journal of Agriculture 13: 188-199.

23) NMA, 2018. Nigerian Meteorological Agency, Margaret Ekpo International Airport, Calabar.

24) Oko OOK, Agiang EA, 2011. Phytochemical activities of Aspilia africana leaf using different extractants. Indian Journal of Animal Sciences 81(8): 814-818.

25) Prabakaran R, 2003. Good practices in planning and management of integrated commercial poultry production in South Asia. Food and Agricultural Organization of the United Nations 159:71-82.

26) Qasem MAA, Alhaj M, Ger El Nabi AB, Al-Mufarrej S, 2015. Effect of high level of turmeric powder as dietary supplement on performance indicators and immune responses in broiler chickens. Journal of Animal Veterinary Advances 14: 30-35.

27) Saraswati TR, Tana S, 2016. Physiological condition of first female and male offspring of Japanese quail (Coturnix japonica) whose parents were supplemented by turmeric powder. Journal of World's Poultry Research 6(2): 59-65.

28) Steel RGD, Torrie JH, 1980. Principles and Procedures of Statistics. A biometrical approach, Second Edition. McGraw-Hill, New York, pp 20-90.

29) Vali N, 2009. Growth, feed consumption and carcass composition of Coturnix japonica coturnix psilophorus and reciprocal crosses. Asian Journal of Poultry Sciences 3: 132-137.

30) Yesuf KY, Mersso BT, Bekele TE, 2017. Effects of different levels of turmeric, fenugreek and black cumin on carcass characteristics of broiler chicken. Journal of Livestock Science 8: 11-17. 